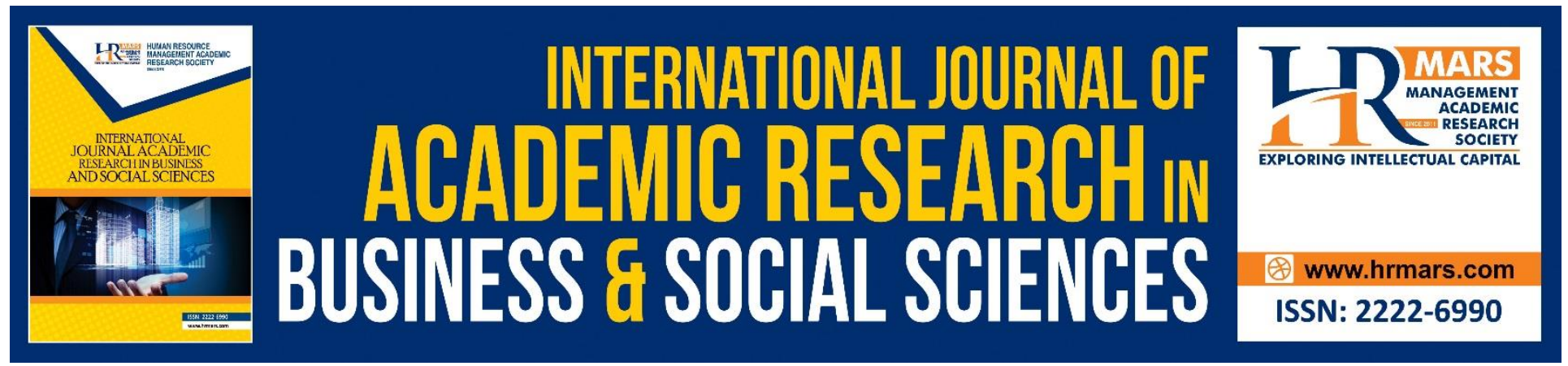

\title{
Perception Level of Visitors towards Shopping's Motivation Factors at the Cross-border Informal Market of Serikin, Sarawak
}

Siti Noradiah Amar, Fariastuti Djafar, Mohammad Affendy Arip, Mohd Khairul Hisyam Hassan, Nur Zaimah Ubaidillah

To Link this Article: http://dx.doi.org/10.6007/IJARBSS/v10-i7/7435

DOI:10.6007/IJARBSS/v10-i7/7435

Received: 04 April 2020, Revised: 08 May 2020, Accepted: 13 June 2020

Published Online: 21 July 2020

In-Text Citation: (Amar et al., 2020)

To Cite this Article: Amar, S. N., Djafar, F., Arip, M. A., Hassan, M. K. H., \& Ubaidillah, N. Z. (2020). Perception Level of Visitors towards Shopping's Motivation Factors at the Cross-border Informal Market of Serikin, Sarawak. International Journal of Academic Research in Business and Social Sciences, 10(7), 460-473.

Copyright: (C) 2020 The Author(s)

Published by Human Resource Management Academic Research Society (www.hrmars.com)

This article is published under the Creative Commons Attribution (CC BY 4.0) license. Anyone may reproduce, distribute, translate and create derivative works of this article (for both commercial and non-commercial purposes), subject to full attribution to the original publication and authors. The full terms of this license may be seen

at: http://creativecommons.org/licences/by/4.0/legalcode

Vol. 10, No. 7, 2020, Pg. 460 - 473

http://hrmars.com/index.php/pages/detail/IJARBSS

JOURNAL HOMEPAGE

Full Terms \& Conditions of access and use can be found at http://hrmars.com/index.php/pages/detail/publication-ethics 


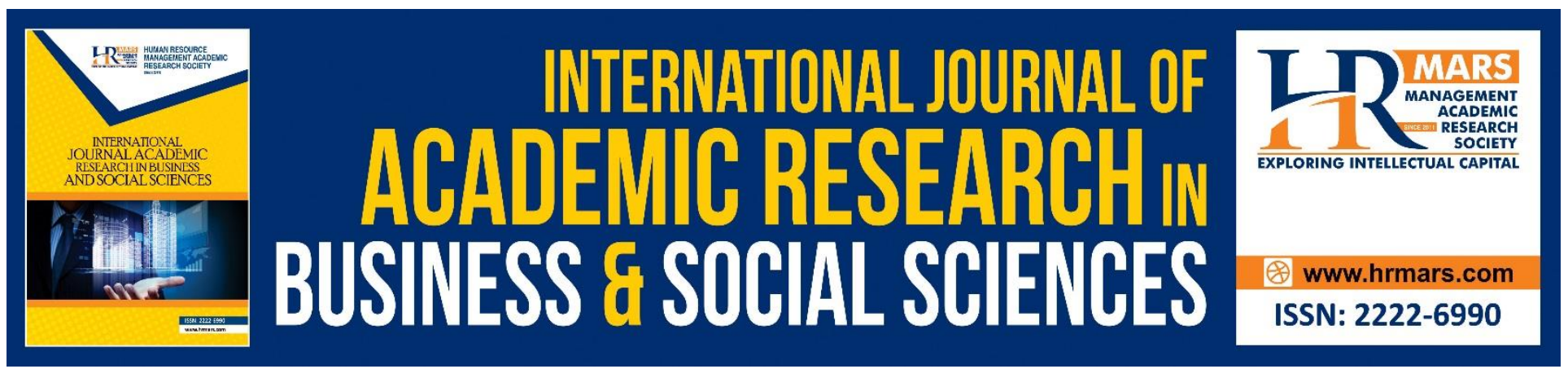

\title{
Perception Level of Visitors towards Shopping's Motivation Factors at the Cross-border Informal Market of Serikin, Sarawak
}

\author{
Siti Noradiah Amar \\ Kolej Yayasan Pelajaran Johor, Malaysia
}

Fariastuti Djafar

Faculty of Economics and Business, Universitas Tanjungpura, Indonesia

\author{
Mohammad Affendy Arip, Mohd Khairul Hisyam Hassan, Nur \\ Zaimah Ubaidillah \\ Faculty of Economics and Business, Universiti Malaysia Sarawak, Malaysia
}

\begin{abstract}
Perception level of the visitors towards shopping motivation factors at the informal cross-border market of Serikin, Sarawak will be examined by using descriptive analysis. There are nine items that are quality of the products, variety of the products, preferences of the products, cheaper price, price and quality of product is consistent, cheaper price due to the cheaper in labor force, bargain hunting, closer, and condition of road. Majority of the visitor's perception towards shopping motivation factors at the informal cross-border market of Serikin, Sarawak are at the neutral level. This is attested by the higher frequency of respondents that give neutral level towards shopping motivation factors. This finding shows that Serikin needs more improvement and development in terms of products, sale's services and environment of shopping to encourage visitors to shop.

Keywords: Perception Level, Visitors, Shopping's Motivation Factors, Sarawak.
\end{abstract}

\section{Introduction}

Border is a kind of political boundary which is set to separate different regions (Timothy, 2005). National boundaries are lines that mark distinct differences in political and ideological system, economics and social structures, and quite simply, ways of life (Ju, 2011). Thus, the function of an international border can significantly affect the economic growth of a country with the presence of tourist from neighbor countries. A border-crossing trip may be concentrated on one activity or a trip may be a multipurpose trip (Kuncharin \& Mohamed, 2013). There are many cross-border activities such as enjoying unique landscape, visiting heritage sites, gambling, sex tourism and one of the important activities is cross-border shopping (Timothy, 2005). Cross-border shopping is of interest 
INTERNATIONAL JOURNAL OF ACADEMIC RESEARCH IN BUSINESS AND SOCIAL SCIENCES Vol. 10, No. 7, July, 2020, E-ISSN: 2222-6990 @ 2020 HRMARS

because of its significant impact on retail sales of shops on both sides of the border. For example, Piron (2002) finds that there are about 900,000 day trippers from Singapore crossing the border to Johor Bahru (southern peninsula Malaysia) for shopping, recreation and food for every month and this huge drainage of retail sales is a serious concern for the Singaporean government. Meanwhile in Brunei, the decline in retail sales is significantly obvious during festive seasons when Bruneians flock to the border towns of Limbang and Miri, Sarawak (Anaman \& Ismail, 2002; The Brunei Times, 2007). Cross-border shopping, therefore, has implications for a country's revenue (Espland et al., 2005; Lau et al., 2005) and generated income, employment and some local economic linkages (Hampton, 2009). Purchases that made by foreigners indicates an export of goods and services in the destination country which might lead to an improvement in the balance of payments and growth.

Generally, the cross-border informal market is one of the mechanisms used to develop the economy of a local community (Titeca, 2010). However, very little attention has been paid on it. As Ibrahim (2010) mentioned, rural border community developments based on the entrepreneurship in Malaysia have received relatively little attention and are not being explored sufficiently. Zinser and Brunswick (2014) also reported relatively scarce academic research on international cross-border activity. In this regard, this study is conducted in Sarawak (Malaysia) - Kalimantan (Indonesia) to enhance more information regarding the informal cross-border market of Serikin, Sarawak. The cross-border activity at Serikin, a small village of Sarawak on the border with Indonesia, is one of the most famous markets and well organized. This market is known as the Weekend Market and very busy during weekends (Saturday and Sunday) because the traders from across the border and nearby areas come to offer their wares and produces. They hawk a variety of authentic Indonesian sarongs, household items and food ranging from farm produce (e.g. vegetables and fruits) to dried seafood and meats. Most of the shops are wooden structured and zinc as a roof built on the right and left side of the 200 meter crossborder road. Every week, the Royal Malaysian Customs at the border of Serikin collects the rental payment from the hawkers. According to the Senior Custom Officer, Jeritish Ak Goneck, the payment depends on the volume of the new goods carried by the traders from Indonesia. Every time traders bring new goods from Indonesia, they will be charged by the custom.

The trading activity at the cross-border informal market between Sarawak (Malaysia) - Kalimantan (Indonesia) seemed slightly declined (Awang et al., 2013). For example, the value of imports from Indonesia to Sarawak (Malaysia) was slightly reduce to RM456.1 million in 2010 compared RM474.0 in 2009 (Department of Statistic, Malaysia 2010, 2011). Does this figure imply that Indonesian products do not have high quality? Or could it be that most of the visitors prefer more to Malaysia products compared to Indonesia products? Based on the above mentioned issues, the general objective of this study is to identify the purchasing pattern of visitors at the cross-border informal market of serikin, Sarawak. Specifically, this study attempts to identify the perception level of visitors towards shopping's motivation factors at the cross-border informal market of Serikin, Sarawak. Conducting this research will be a significant contribution to the literature on informal cross-border market. This study would add to the existing literature on cross-border shopping as well as contribute to the development of predictive model building and possible theory development. The results also provide valuable information to the marketing planners, media companies and others to better target and attract cross-border visitors. Section 2 presents the literature review on theoretical and empirical 